\title{
FAKTOR-FAKTOR YANG MENYEBABKAN KETIDAKBERHASILAN PEMBERIAN ASI EKSLUSIF MELALUI KELOMPOK PENDUKUNG ASI (KP-ASI)
}

\author{
Besti Verawati $^{1}$, Nopri Yanto ${ }^{2}$,Indrawati ${ }^{3}$,Yufi Permata Dewi \\ S1 Gizi Universitas Pahlawan Tuanku Tambusai Riau ${ }^{1,4}$ \\ S1 Keperawatan Universitas Pahlawan Tuanku Tambusai Riau ${ }^{2}$ \\ D3 Keperawatan Universitas Pahlawan Tuanku Tambusai Riau ${ }^{3}$ \\ bestiverawati167@gmail.com ${ }^{1}$,nopriyantocantika@gmail.com ${ }^{2}$
}

\begin{abstract}
The lowest coverage rate of exclusive breastfeeding in 2019 was found in the Sidomulyo Health Center working area of 33.7\%. One of the factors that influence the low level of exclusive breastfeeding is the lack of encouragement and support from family and the environment. Support from the environment can be realized by forming a breastfeeding support group (KP-ASI). The purpose of this study was to analyze the factors that cause the unsuccessfulness of exclusive breastfeeding through breastfeeding support groups (KP-ASI) at Sidomulyo Health Center Pekanbaru. This type of research is quantitative with cross sectional method. This research was conducted on 02 June - 17 June 2020 at Puskesmas Sidomulyo Pekanbaru with a sample size of 25 KP-ASI members and 25 infant mothers. The technique of collecting interview data using a questionnaire. The analysis used was univariate and bivariate with the Chi Square test. The results of univariate analysis showed that most 13 people (52\%) had good motivation, most of the availability of infrastructure, 14 people (56\%) were in the inadequate category and supervision, namely 13 people $(52 \%)$ were in the poor category The results showed a $p$ value of 0.028 for the motivation variable, 0.070 for the variable availability of infrastructure and 0.025 for the monitoring variable. The conclusion is there is a relationship between motivation and supervision with the practice of exclusive breastfeeding. Meanwhile, seen from the $p$ value $>0.05$ for the variable availability of infrastructure, there is no relationship between the availability of infrastructure and the practice of exclusive breastfeeding.
\end{abstract}

Keywords : Breastfeeding Support Groups, Exclusive Breastfeeding On Breasts, Motivation, Supervision And Infrastructure.

\begin{abstract}
ABSTRAK
Angka cakupan pemberian ASI eksklusif terendah pada tahun 2019 diantaranya terdapat di wilayah kerja Puskesmas Sidomulyo sebesar 33,7\%. Salah satu faktor yang mempengaruhi rendahnya pemberian ASI Eksklusif adalah kurangnya dorongan dan dukungan dari keluarga dan lingkungan. Dukungan dari lingkungan dapat diwujudkan dengan pembentukan kelompok pendukung ASI (KPASI). Tujuan penelitian ini adalah untuk menganalisis faktor-faktor yang menyebabkan ketidakberhasilan pemberian ASI Ekslusif melalui Kelompok Pendukung ASI (KP-ASI) di Puskesmas Sidomulyo Pekanbaru. Jenis penelitian ini adalah kuantitatif dengan metode cross sectional. Penelitian ini dilakukan pada tanggal 02 Juni - 17 Juni 2020 di Puskesmas Sidomulyo Pekanbaru dengan jumlah sampel 25 anggota KP-ASI dan 25 ibu bayi. Teknik pengumpulan data wawancara menggunakan kuesioner. Analisa yang digunakan adalah univariat dan bivariat dengan uji Chi Square. Hasil analisa univariat menunjukkan sebagian besar yaitu 13 orang (52\%) memiliki motivasi termasuk kategori baik, sebagian besar ketersediaan sarana prasarana yaitu 14 orang $(56 \%)$ termasuk dalam kategori tidak memadai dan pengawasan yaitu 13 orang (52\%) termasuk dalam kategori kurang. Hasil penelitian menunjukkan p value 0,028 untuk variable motivasi, 0,070 untuk variable ketersediaan sarana prasarana dan 0,025 untuk variable pengawasan. Ada hubungan antara motivasi dan pengawasan dengan praktik pemberian ASI Eksklusif. Sedangkan dilihat dari p value > 0,05 untuk
\end{abstract}


variable ketersediaan sarana prasarana maka tidak ada hubungan antara ketersediaan sarana prasarana dengan praktik pemberian ASI Eksklusif.

Kata Kunci : ASI Eksklusif Pada Payi, Kelompok Pendukung ASI, Motivasi, Pengawasan Dan Sarana Prasarana.

\section{PENDAHULUAN}

Pertumbuhan dan perkembangan yang optimal baik fisik maupun mental serta kecerdasan bayi dipengaruhi oleh Air Susu Ibu (ASI). ASI merupakan makanan terbaik bagi bayi karena mengandung komposisi yang lengkap. Pemberian ASI Eksklusif pada bayi adalah bayi hanya diberi ASI saja, tanpa tambahan cairan lain seperti susu formula, air jeruk, madu, air teh, air putih dan tanpa tambahan makanan padat seperti pisang, pepaya, bubur susu, biskuit, bubur nasi dan tim, selama 6 bulan (Mufdlilah, 2013). World Health Organization (WHO) dan United Nation Children Fund (UNICEF) telah merekomendasikan program ASI eksklusif pada bayi usia 0-6 bulan. Hal ini sejalan dengan Keputusan Menteri Kesehatan RI No.450/Menkes/IV/2004 yang menetapkan bahwa ASI merupakan makanan terbaik bagi bayi, untuk mencapai pertumbuhan dan perkembangan yang optimal (Kementerian Kesehatan RI (Kemenkes RI), 2015). Hal ini juga sesuai dengan Peraturan Menteri Negara Pemberdayaan Perempuan dan Perlindungan Anak Republik Indonesia Nomor 03 Tahun 2010 tentang penerapan sepuluh langkah menuju keberhasilan menyusui salah satunya yaitu pembentukan Kelompok Pendukung ASI.

Target pemberian ASI Eksklusif secara nasional ditetapkan sebesar $80 \%$. Berdasarkan Riset Kesehatan Dasar (Riskesdas) tahun 2018, cakupan ASI Eksklusif di Indonesia masih dibawah target nasional yaitu 37,3\%. Persentase pemberian ASI eksklusif di Provinsi Riau sebesar 65\% dan untuk di Kota Pekanbaru, rata-rata cakupan pemberian ASI eksklusif pada tahun 2019 sebesar $41 \%$. Angka cakupan pemberian ASI eksklusif terendah diantaranya terdapat di wilayah kerja
Puskesmas Sidomulyo sebesar 33,7\% pada tahun 2019.

Cakupan pemberian ASI eksklusif yang rendah pada bayi usia 0-6 bulan dapat disebabkan oleh rendahnya pengetahuan di masyarakat mengenai ASI eksklusif, bahkan tenaga kesehatan juga kurang mengerti tentang keunggulan dan berbagai manfaat penting dari ASI eksklusif (Kemenkes RI, 2010). Pengetahuan ibu, dukungan sosial, dukungan tenaga kesehatan, sosial budaya, serta faktor-faktor sosiodemografi lainnya saat ini sering dihubungkan dengan rendahnya pemberian ASI Eksklusif. Faktor yang dapat menghambat pemberian ASI secara eksklusif yang tidak kalah pentingnya adalah kurangnya dorongan dari keluarga seperti suami atau orang tua dan lingkungan yang dapat menurunkan semangat ibu untuk menyusui dan mengurangi motivasi ibu untuk menyusui (Mawadddah, 2018).

Salah satu faktor yang mempengaruhi rendahnya pemberian ASI Eksklusif adalah kurangnya dorongan dan dukungan dari keluarga dan lingkungan. Dukungan dari lingkungan dapat diwujudkan dengan pembentukan kelompok pendukung ASI (KP-ASI). KPASI merupakan wadah bagi keluarga dan lingkungan ibu menyusui untuk memotivasi dalam beberapa metode seperti diskusi dan pemaparan terkait kesehatan pada ibu menyusui.

Pembentukan Kelompok Pendukung ASI (KP-ASI) eksklusif penting dibentuk karena ibu merasa didukung, dicintai dan diperhatikan, maka akan muncul emosi positif yang akan meningkatkan produksi hormon oksitosin sehingga produksi ASI lancar. Adanya pembentukan Kelompok Pendukung ASI Eksklusif di 
Puskesmas Sidomulyo dapat memberikan manfaat dan meningkatkan pemberian ASI Eksklusif pada bayi yang dapat diukur dari praktik yang dilakukan ibu. Praktik adalah reaksi/tindakan seseorang terhadap suatu stimulus. Pada bidang gizi, praktik merupakan respon yang berkaitan dengan makanan, zat-zat gizi dan penyakit baik secara aktif yang dilakukan seseorang sehubungan dengan status kesehatan yang dimiliki (Notoatmodjo, 2012).

Pembentukan KP-ASI di Kelurahan Tuah Karya dilakukan pada bulan Agustus 2018. KP-ASI memiliki kegiatan berupa penyuluhan, pendampingan dan konsultasi yang dijadwalkan setiap bulannya pada ibu menyusui. Program ini masih berjalan hingga tahun 2019 namun belum dilakukan monitoring dan evaluasi terkait pengaruh pembentukan KP-ASI tersebut terhadap praktik pemberian ASI Eksklusif di Kelurahan Tuah Karya.

Kendala yang selama ini dirasakan dalam pencapaian cakupan adalah kurangnya motivasi dari anggota KP-ASI, ketersediaan sarana prasarana dan kurangnya pengawasan. Studi terkait KPASI telah banyak dilakukan seperti pada penelitian Nurrahman (2017) tentang Pengetahuan, Sikap dan Praktik Pemberian ASI Eksklusif dengan jenis penelitian cross sectional. Sampel sejumlah 102 orang dengan teknik pengambilan sampel yaitu accidental sampling. Hasil penelitian ini menunjukkan bahwa, hubungan pemberian ASI Eksklusif dengan pengetahuan ibu diperoleh hasil uji statistik yaitu nilai $p=0,877>0,05$, tidak ada hubungan antara praktik pemberian ASI Eksklusif dengan pengetahuan ibu. Sedangkan hubungan pemberian ASI Eksklusif dengan sikap diperoleh hasil uji statistik yaitu nilai $\mathrm{p}=0,000<0,05$, ada hubungan antara praktik pemberian ASI Eksklusif dengan sikap ibu dengan tingkat keeratan hubungan kuat $(\alpha=0,674)$.

Tujuan penelitian ini adalah menganalisis faktor-faktor yang menyebabkan ketidakberhasilan pemberian ASI Ekslusif melalui Kelompok Pendukung ASI (KP-ASI) di Puskesmas Sidomulyo Pekanbaru.

\section{METODE}

Jenis penelitian ini merupakan penelitian korelasional dengan desain cross sectional. Penelitian ini dilaksanakan pada bulan Mei 2020 di Puskesmas Sidomulyo Kota Pekanbaru. Sampel dalam penelitian ini adalah 25 orang anggota KPASI dan 25 orang ibu yang memiliki bayi usia 6-12 bulan yang sudah mendapat pendampingan KP-ASI.

Instrumen penelitian yang digunakan adalah kuesioner digunakan untuk mengetahui motivasi, sarana dan prasarana, pengawasan. Uji statistic yang digunakan adalah uji Chi Square.

\section{HASIL}

\section{Analisa Univariat}

Tabel 1 Distribusi Frekuensi berdasarkan Karakteristik Responden

\begin{tabular}{lcccc}
\hline Karakteristik & KP-ASI & \multicolumn{2}{c}{ Ibu bayi } \\
\cline { 2 - 5 } & $\mathbf{N}$ & $\mathbf{\%}$ & $\mathbf{n}$ & \% \\
\hline Usia & & & 9 & 36 \\
Remaja akhir (17-25 tahun) & 0 & 0 & 16 & 64 \\
Dewasa awal (26-35 tahun) & 7 & 58 & 0 & 0 \\
Dewasa akhir (36-45 tahun) & 14 & 16 & 0 & 0 \\
Lansia awal (45-55 tahun) & 4 & 100 & 25 & 100 \\
\hline Total & 25 & 36 & 3 & 12 \\
\hline Pendidikan & & 36 & & \\
S1 & 9 & & & \\
\hline
\end{tabular}




\begin{tabular}{lcccc}
\hline D3 & 7 & 28 & 5 & 20 \\
SMA & 8 & 32 & 17 & 68 \\
SMP & 1 & 4 & 0 & 0 \\
\hline Total & 25 & 100 & 25 & 100 \\
\hline
\end{tabular}

Berdasarkan tabel 1 dari 25 orang anggota KP-ASI sebagian besar yaitu sebanyak 14 orang $(56 \%)$ termasuk dalam kategori dewasa akhir (36-45 tahun) dan sebagian besar ibu bayi yakni sebanyak 16 orang (64\%)termasuk dalam kategori usia dewasa awal. Selanjutnya hampir sepertiga anggota KP-ASI pendidikannya S1 yakni berjumlah 9 orang $(36 \%)$ sedangkan ibu bayi sebagian besar yaitu sebanyak 17 orang $(68 \%)$. berpendidikan SMA.

Tabel 2 Distribusi Frekuensi Motivasi KPASI di Puskesmas Sidomulyo

\begin{tabular}{lcc}
\hline Motivasi & Frekuensi (n) & Persentase (\%) \\
\hline Baik & 13 & 52 \\
Kurang & 12 & 48 \\
\hline Total & 25 & 100 \\
\hline
\end{tabular}

Berdasarkan tabel 2 dari 25 orang sebagian besar KP-ASI yaitu berjumlah 13 orang $(52 \%)$ termasuk dalam kategori motivasi baik.

Tabel 3 Distribusi Frekuensi Ketersediaan Sarana Prasarana KP-ASI di Puskesmas Sidomulyo

\begin{tabular}{lcc}
\hline $\begin{array}{l}\text { Ketersediaan } \\
\text { Sarana }\end{array}$ & $\begin{array}{c}\text { Frekuensi } \\
\text { Prasarana }\end{array}$ & $\begin{array}{c}\text { Persentase } \\
(\boldsymbol{\%})\end{array}$ \\
\hline Memadai & 11 & 44 \\
Tidak memadai & 14 & 56 \\
\hline Total & 25 & 100 \\
\hline
\end{tabular}

Berdasarkan tabel 3 dari 25 orang KP-ASI sebagian besar yaitu berjumlah 14 orang $(56 \%)$ merasa ketersediaan sarana prasarana termasuk dalam kategori tidak memadai.

Tabel 4 Distribusi Frekuensi Pengawasan KP-ASI di Puskesmas Sidomulyo

\begin{tabular}{lcc}
\hline Pengawasan & $\begin{array}{c}\text { Frekuensi } \\
\text { (n) }\end{array}$ & Persentase (\%) \\
\hline Baik & 14 & 56 \\
Kurang & 11 & 44 \\
\hline Total & 25 & 100 \\
\hline
\end{tabular}

Berdasarkan tabel 4 dari 25 orang KPASI sebagian besar yaitu sejumlah 14 orang $(56 \%)$ merasa pengawasan dari petugas telah baik.

Tabel 5 Distribusi Frekuensi Praktik Pemberian ASI Eksklusif di Puskesmas Sidomulyo

\begin{tabular}{lcc}
\hline Praktik & $\begin{array}{c}\text { Frekuensi } \\
(\mathbf{n})\end{array}$ & $\begin{array}{c}\text { Persentase } \\
(\boldsymbol{\%})\end{array}$ \\
\hline ASI Eksklusif & 12 & 48 \\
Tidak Eksklusif & 13 & 52 \\
\hline Total & 25 & 100 \\
\hline
\end{tabular}

Berdasarkan tabel 5 dari 25 orang KP-ASI sebagian besar ibu bayi yakni berjumlah 13 orang (52\%)belum melakukan praktik pemberian ASI secara eksklusif.

\section{Analisa Bivariat}

Tabel 6 Hubungan Motivasi dan Praktik Pemberian ASI $\quad$ Eksklusif di Puskesmas Sidomulyo

\begin{tabular}{|c|c|c|c|c|c|c|c|}
\hline \multirow{3}{*}{ Motivasi } & \multicolumn{4}{|c|}{ Praktik Pemberian ASI Eksklusif } & \multicolumn{2}{|c|}{ Total } & \multirow{2}{*}{$p$ value } \\
\hline & \multicolumn{2}{|c|}{ Tidak eksklusif } & \multicolumn{2}{|c|}{ ASI Eksklusif } & & & \\
\hline & $\mathrm{n}$ & $\%$ & $\mathrm{n}$ & $\%$ & $\mathrm{n}$ & $\%$ & \\
\hline Kurang & 3 & 25 & 9 & 75 & 12 & 100 & 0,009 \\
\hline Baik & 10 & 76,9 & 3 & 23,1 & 13 & 100 & \\
\hline Total & 13 & 52 & 12 & 48 & 25 & 100 & \\
\hline
\end{tabular}

Berdasarkan tabel dari 12 orang anggota KP-ASI yang memiliki motivasi kurang terdapat 9 orang $(75 \%)$ ibu bayi yang menerapkan ASI Eksklusif. 
Kemudian dari 13 orang KP-ASI yang memiliki motivasi terdapat 10 orang $(76,9 \%)$ ibu bayi yang tidak menerapkan ASI Eksklusif. Berdasarkan uji Chi Square didapatkan $\mathrm{p}$ value $<0,05(0,009)$ artinya ada hubungan motivasi KP-ASI dengan praktik pemberian ASI Eksklusif di
Puskesmas Sidomulyo dengan OR 0,100 ini menunjukkan bahwa anggota KP-ASI dengan motivasi yang baik memiliki peluang 0,185 kali lebih besar dalam memberikan pendampingan kepada ibu bayi untuk menerapkan pemberian ASI secara eksklusif

Tabel 7 Hubungan Ketersediaan Sarana Prasarana dan Praktik Pemberian ASI Eksklusif di Puskesmas Sidomulyo

\begin{tabular}{|c|c|c|c|c|c|c|c|}
\hline \multirow{3}{*}{$\begin{array}{c}\text { Ketersediaan sarana } \\
\text { prasarana }\end{array}$} & \multicolumn{4}{|c|}{ Praktik Pemberian ASI Eksklusif } & \multicolumn{2}{|c|}{ Total } & \multirow[t]{3}{*}{ p value } \\
\hline & \multicolumn{2}{|c|}{ Tidak eksklusif } & \multicolumn{2}{|c|}{ ASI Eksklusif } & & & \\
\hline & $\mathrm{n}$ & $\%$ & $\mathrm{n}$ & $\%$ & $n$ & $\%$ & \\
\hline Tidak memadai & 10 & 71,4 & 4 & 28,6 & 14 & 100 & 0,028 \\
\hline Memadai & 3 & 27,3 & 8 & 72,7 & 11 & 100 & \\
\hline Total & 13 & 52 & 12 & 48 & 25 & 100 & \\
\hline
\end{tabular}

Berdasarkan tabel 7 dari 14 orang KP-ASI yang merasa ketersediaan sarana prasarana tidak memadai terdapat 4 $(28,6 \%)$ ibu bayi yang menerapkan pemberian ASI eksklusif. Kemudian dari 11 orang anggota KP-ASI yang merasa ketersediaan sarana prasarana memadai terdapat 3 orang $(27,3 \%)$ ibu bayi yang tidak menerapkan pemberian ASI eksklusif. Hasil uji menunjukkan p value < $0,05(0,028)$ hal ini menunjukkan ada hubungan ketersediaan sarana prasarana Kelompok Pendukung ASI (KP-ASI) dengan praktik pemberian ASI Eksklusif di Puskesmas Sidomulyo Pekanbaru. Kemudian didapatkan nilai OR 6,667 ini menunjukkan bahwa ketersediaan sarana prasarana KP-ASI yang memadai memiliki peluang 6,667 kali lebih besar dalam memberikan pendampingan kepada ibu bayi untuk menerapkan pemberian ASI secara eksklusif.

Tabel 8 Hubungan Pengawasan dan Praktik Pemberian ASI Eksklusif di Puskesmas Sidomulyo

\begin{tabular}{|c|c|c|c|c|c|c|c|}
\hline \multirow{3}{*}{ Pengawasan } & \multicolumn{4}{|c|}{ Praktik Pemberian ASI Eksklusif } & \multicolumn{2}{|c|}{ Total } & \multirow[t]{2}{*}{ p value } \\
\hline & \multicolumn{2}{|c|}{ Tidak eksklusif } & \multicolumn{2}{|c|}{ ASI Eksklusif } & & & \\
\hline & $\mathrm{F}$ & $\%$ & $\mathrm{~F}$ & $\%$ & $\mathrm{~F}$ & $\%$ & \\
\hline Kurang & 9 & 81,8 & 2 & 18,2 & 11 & 100 & 0,008 \\
\hline Baik & 4 & 28,6 & 10 & 71,4 & 14 & 100 & \\
\hline Total & 13 & 52 & 12 & 48 & 25 & 100 & \\
\hline
\end{tabular}

Berdasarkan tabel 8 dari 11 orang KP-ASI yang merasa pengawasan kurang terdapat 2 orang $(18,2 \%)$ ibu bayi yang telah menerapkan pemberian ASI secara Eksklusif. Kemudian dari 14 orang KPASI termasuk dalam kategori pengawasan yang baik terdapat 4 orang $(28,6 \%)$ ibu yang menerapkan pemberian ASI secara Eksklusif. Berdasarkan hasil uji didapatkan $\mathrm{p}$ value $<0,05(0,008)$. Hal ini menunjukkan ada hubungan pengawasan kegiatan Kelompok Pendukung ASI (KPASI) dengan praktik pemberian ASI Eksklusif di Puskesmas Sidomulyo Pekanbaru. Nilai OR 11,25 ini menunjukkan bahwa pengawasan kepada KP-ASI yang baik memiliki peluang 11,25 kali lebih besar dalam memberikan pendampingan kepada ibu bayi untuk 
menerapkan pemberian ASI secara eksklusif.

\section{PEMBAHASAN}

\section{Analisa Univariat \\ Motivasi Kelompok Pendukung ASI Eksklusif (KP-ASI)}

Berdasarkan hasil analisa univariat dari 25 orang KP-ASI sebagian besar KPASI yaitu berjumlah 13 orang (52\%) termasuk dalam kategori motivasi baik. Menurut peneliti motivasi baik ini terlihat pada saat dilakukan wawancara pada anggota KP-ASI dimana anggota KP-ASI mendapatkan dorongan dari sesama anggota untuk menjalankan kegiatan KPASI tersebut. Motivasi yang didapatkan dari anggota mendorong KP-ASI melakukan kegiatan tersebut dengan optimal ditambah lagi mereka merasa memiliki tanggung jawab untuk meningkatkan cakupan ASI Eksklusif di wilayahnya. Hal ini sejalan dengan penelitian Ervada (2018) tentang "Hubungan Dukungan Motivator dengan Motivasi Peserta Kelompok Pendukung Ibu di Wilayah Kerja Puskesmas Sangkrah" dengan sampel 202 orang. Hasil analisa univariat menunjukkan bahwa 50\% motivator memiliki motivasi yang baik. Hasil uji ada hubungan antara dukungan emosional dengan motivasi peserta $(\mathrm{p}=0,016)$, dukungan instrumental dengan motivasi peserta $(p=0,000)$, dukungan informasi dengan motivasi peserta $(p=0,004)$. Tidak terdapat hubungan dukungan penghargaan dengan motivasi peserta.

Motivasi adalah daya upaya yang mendorong seseorang melakukan sesuatu. Motif dapat dikatakan sebagai daya penggerak dari dalam diri subyek untuk melakukan aktivitas tertentu demi mencapai tujuan. (Sardiman, 2011). Motivasi yang baik dari anggota KP-ASI dapat mendorong agar tercapainya tujuan dari program yakni meningkatkan cakupan ASI Eksklusif di Puskesmas Sidomulyo.

\section{Ketersediaan Sarana Prasarana Kelompok Pendukung ASI Eksklusif (KP-ASI)}

Berdasarkan hasil analisa univariat dari 25 orang KP-ASI sebagian besar yaitu berjumlah 14 orang (56\%) merasa ketersediaan sarana prasarana termasuk dalam kategori tidak memadai. Menurut peneliti melalui wawancara dan juga observasi terlihat sarana prasarana yang ada belum memadai seperti alat peraga menyusui yang terbatas. Begitu juga dengan media yang digunakan untuk melakukan pendampingan masih belum mencukupi seperti leaflet, brosur dan sebagainya. Hal ini sejalan dengan penelitian Nurdiana (2015) tentang "Hubungan Tingkat Pengetahuan Ibu dan Ketersediaan Fasilitas Penunjang Asi Eksklusif dengan Pemberian ASI di Wilayah Kerja Puskesmas Bonorowo Kabupaten Kebumen" dengan sampel adalah ibu yang mempunyai bayi usia 7 sampai 12 bulan yang berjumlah 242 responden. Hasil penelitian menunjukkan $41,7 \%$ ibu merasa ketersediaan fasilitas masih kurang.

Sarana prasarana adalah suatu usaha pengadaan dan pemeliharaan alat benda yang bergerak maupun yang tidak digunakan untuk menunjang kelancaran proses kegiatan suatu program baik secara langsung maupun tidak langsung untuk mencapai tujuan yang efektif dan efisien. Tujuan sarana prasarana adalah memberikan layanan serta profesionalisme dalam rangka terselenggara proses kegiatan program secara efektif dan efisien (Nurdiana, 2015).

\section{Pengawasan Kelompok Pendukung ASI Eksklusif (KP-ASI)}

Berdasarkan hasil analisa univariat dari 25 orang KP-ASI sebagian besar yaitu sejumlah 14 orang $(56 \%)$ merasa 
pengawasan dari petugas telah baik. Pengawasan dari petugas setempat seperti petugas puskesmas, petugas kelurahan dan tokoh masyarakat sudah baik. Dari hasil wawancara dapat dilihat koordinasi yang baik antar petugas dan juga anggota KPASI. Hal ini juga terlihat melalui dilakukannya pertemuan-pertemuan antar lintas sektor terkait kegiatan tersebut. Hal ini sejalan dengan penelitian Hervilia (2016) tentang "Hambatan Kinerja Konselor Menyusui dalam Meningkatkan Cakupan Pemberian ASI Eksklusif di Kota Kupang" dengan informan penelitian ini adalah konselor ASI $(n=17)$ dan penanggung jawab program gizi dan KIA Dinas Kesehatan Kota Kupang $(n=1)$. Penelitian dilakukan dengan metode indepth interview. Hasil penelitian menunjukkan bahwa hambatan terbesar yang dimiliki konselor menyusui adalah motivasi dalam melaksanakan tugas sebagai konselor. Hal ini disebabkan oleh kebutuhan akan dana tambahan yang belum terpenuhi dan kurangnya pengawasan terhadap kegiatan konseling menyusui. Kesimpulan dari penelitian ini adalah pemberian motivasi, perbaikan sarana prasarana, dan monitoring evaluasi secara berkala diperlukan untuk menunjang kegiatan konseling menyusui sehingga dapat membantu menyukseskan program ASI eksklusif di wilayah Kota Kupang.

Pengawasan adalah fungsi di dalam manajemen fungsional yang harus dilaksanakan oleh setiap pimpinan semua unit/satuan kerja terhadap pelaksanaan pekerjaan atau petugas yang melaksanakan sesuai dengan tugas pokoknya masingmasing. Dengan demikian, pengawasan oleh pimpinan khususnya yang berupa pengawasan melekat (built in control), merupakan kegiatan manajerial yang dilakukan dengan maksud agar tidak terjadi penyimpangan dalam melaksanakan pekerjaan (Kadarisman, 2013).
Pengawasan oleh petugas yang baik pada anggota KP-ASI dapat meningkatkan peluang berhasilnya program tersebut. Hal ini dikarenakan dengan adanya pengawasan oleh petugas kinerja KP-ASI dapat terus di pantau agar bekerja sesuai dengan tugas dan fungsinya.

\section{Praktik Pemberian ASI Eksklusif}

Berdasarkan hasil analisa univariat dari 25 orang KP-ASI sebagian besar ibu bayi yakni berjumlah 13 orang (52\%)belum melakukan praktik pemberian ASI secara eksklusif. Menurut asumsi peneliti masih banyaknya ibu bayi yang belum menerapkan praktik pemberian ASI Eksklusif. Hal ini terlihat dari observasi dan wawancara mendalam pada ibu bayi masih banyaknya yang memberikan makanan sebelum bayi berusia 6 bulan. Ada juga ibu yang mengatakan bahwa anaknya diberikan susu formula karena ASI ibu tersebut tidak keluar. Penelitian ini sejalan dengan penelitian Ichsan (2015) tentang "Keefektifan Program Kelompok Pendukung Ibu dalam Mengubah Perilaku Ibu Menyusui" dengan besar sampel yaitu 384 ibu yang memiliki bayi berusia 6-24 bulan. Hasil uji Mann-Whitney menunjukkan bahwa pengetahuan dan sikap tentang ASI eksklusif pada ibu-ibu yang mengikuti program pendukung ibu lebih tinggi secara bermakna dibanding ibu-ibu yang tidak mengikuti $(\mathrm{p}=0,04$ dan $\mathrm{p}=0,001)$. Uji Chi-Square menunjukkan bahwa tidak terdapat perbedaan tindakan yang bermakna pada kelompok tersebut $(\mathrm{p}=0,82)$.

Praktik adalah suatu sikap yang terwujud dalam bentuk tindakan. ASI eksklusif adalah pemberian ASI saja tanpa tambahan cairan seperti susu formula, jeruk, madu, air teh, air putih dan tanpa tambahan makanan padat seperti pisang, pepaya, bubur susu, biskuit, bubur nasi dan tim (Arini, 2012). Praktik Pemberian ASI eksklusif adalah tindakan yang dilakukan ibu untuk menerapkan pemberian ASI saja 
tanpa tambahan makanan lainnya pada bayi usia 0-6 bulan.

\section{Analisa Bivariat}

Analisa bivariat menggunakan uji Chi Square dengan derajat kepercayaan (Convidence Interval) yang digunakan $95 \%$ dan $\square=0,05$ untuk mengetahui adanya hubungan antar variabel.

\section{Hubungan Motivasi dan Praktik Pemberian ASI Eksklusif}

Berdasarkan analisa bivariat dari 12 orang anggota KP-ASI yang memiliki motivasi kurang terdapat 9 orang $(75 \%)$ ibu bayi yang menerapkan ASI Eksklusif. Kemudian dari 13 orang KP-ASI yang memiliki motivasi terdapat 10 orang (76,9\%) ibu bayi yang tidak menerapkan ASI Eksklusif. Berdasarkan uji Chi Square didapatkan $\mathrm{p}$ value $<0,05(0,009)$ artinya ada hubungan motivasi KP-ASI dengan praktik pemberian ASI Eksklusif di Puskesmas Sidomulyo dengan OR 0,100 ini menunjukkan bahwa anggota KP-ASI dengan motivasi yang baik memiliki peluang 0,185 kali lebih besar dalam memberikan pendampingan kepada ibu bayi untuk menerapkan pemberian ASI secara eksklusif..

Menurut asumsi peneliti motivasi sangat mempengaruhi tindakan seseorang sehingga motivasi anggota KP-ASI akan sangat menentukan praktik pemberian ASI Eksklusif oleh ibu bayi. Namun motivasi dari KP-ASI bukanlah satu-satunya penentu pemberian ASI Ekkslusif pada bayi. Hal ini terlihat dari hasil penelitian dimana meskipun motivasi dari KP-ASI kurang namun masih ada ibu bayi yang menerapkan ASI Eksklusif dan juga KPASI yang memiliki motivasi baik namun masih ada ibu bayi yang tidak menerapkan pemberian ASI Eksklusif. Faktor lainnya yang mempengaruhi pemberian ASI Eksklusif adalah dukungan dari keluarga dan ibu telah mengetahui sebelumnya pentingnya pemberian ASI Eksklusif pada bayi.

Penelitian ini sejalan dengan penelitian Sutaryono (2015) tentang Pembentukan Kelompok Pendukung Air Susu Ibu (ASI) Muhammadiyah Klaten dimana pembentukan kelompok secara kelembagaan telah kuat dan mandiri dengan memiliki administratif yang baik, mengadakan pelatihan motivator dengan peserta 418 orang, kunjungan lapangan, serta mengadakan penyuluhan ASI dan pemberian makanan pendamping anak untuk pengungsi korban bencana gunung merapi. Motivator yang telah dilatih diharuskan mampu memberikan penyuluhan tentang pemberian ASI terhadap ibu-ibu yang memiliki bayi dilingkungan sekitarnya. Hasil penelitian menunjukkan motivasi dari motivator sangat mempengaruhi pemberian ASI Eksklusif pada bayi.

Motivasi memiliki pengaruh yang signifikan terhadap kinerja seseorang. Motivasi merupakan penggerak kegairahan kerja seseorang agar mereka mau bekerja sama, bekerja efektif, dan terintegritas dengan segala daya upaya untuk mencapai kepuasan. Motivasi kerja akan mendorong seseorang untuk bekerja. Motivasi kerja seseorang sangat dipengaruhi oleh perasaan "butuh" individu tersebut untuk melakukan sesuatu (Misransyah, 2012).

Faktor-faktor yang dapat menurunkan motivasi adalah penyebab ketidakpuasan yang meliputi kondisi kerja yang buruk, pengawasan yang inkompeten, gaji yang rendah, kebijakan perusahaan (program) yang tidak efisien, hubungan personal yang buruk, dan mutu kepemimpinan yang buruk. Faktor yang dapat meningkatkan motivasi adalah penyebab kepuasan atau hasil kerja itu sendiri. Kepuasan terhadap hasil kerja merupakan faktor yang sangat mempengaruhi motivasi kerja, dan motivasi kerja sangat mempengaruhi komitmen terhadap tugas yang akan 
dilaksanakan. Komitmen yang kuat akan mendasari tanggung jawab/kewajiban untuk melaksanakan pekerjaan dengan baik serta untuk mengembangan pekerjaannya (Rayadi,2012).

\section{Hubungan Ketersediaan Sarana Prasarana dan Praktik Pemberian ASI Eksklusif}

Berdasarkan hasil analisa bivariat dari 14 orang KP-ASI yang merasa ketersediaan sarana prasarana tidak memadai terdapat $4(28,6 \%)$ ibu bayi yang menerapkan pemberian ASI eksklusif. Kemudian dari 11 orang anggota KP-ASI yang merasa ketersediaan sarana prasarana memadai terdapat 3 orang $(27,3 \%)$ ibu bayi yang tidak menerapkan pemberian ASI eksklusif . Hasil uji menunjukkan $\mathrm{p}$ value $<0,05(0,028)$ hal ini menunjukkan ada hubungan ketersediaan sarana prasarana Kelompok Pendukung ASI (KPASI) dengan praktik pemberian ASI Eksklusif di Puskesmas Sidomulyo Pekanbaru. Kemudian didapatkan nilai OR 6,667 ini menunjukkan bahwa ketersediaan sarana prasarana KP-ASI yang memadai memiliki peluang 6,667 kali lebih besar dalam memberikan pendampingan kepada ibu bayi untuk menerapkan pemberian ASI secara eksklusif.

Menurut asumsi peneliti ketersediaan sarana prasarana memang merupakan unsur penting dalam berlangsungnya sebuah kegiatan. Dari hasil analisa dapat dilihat meski ketersediaan sarana prasarana yang tidak memadai namun ibu bayi tetap memberikan ASI secara eksklusif begitu juga sebaliknya dimana ketersediaan sarana prasarana memadai tetapi ibu tidak memberikan ASI secara eksklusif. Hal ini disebabkan oleh pemanfaatan sarana prasarana saat melakukan pendampingan bergantung pada anggota KP-ASI. Jika sarana prasarana dapat dimanfaatkan secara efektif maka akan berdampak pada penerimaan informasi oleh ibu bayi sehingga ibu akan menerapkan pemberian ASI secara eksklusif.

Ketersediaan sarana prasarana dapat mendukung kelancaran jalannya kegiatan KP-ASI. Sarana prasarana yang dimaksud seperti gedung tempat melakukan pertemuan, media dan alat peraga untuk melakukan pendampingan. Jika semua sarana prasarana tersebut telah memadai maka anggota KP-ASI dapat melakukan penyampaian informasi secara efektif. Ibu bayi juga akan menerima dan memahami informasi terkait pemberian ASI secara eksklusif dengan baik karena didukung adanya media seperti leaflet, poster, spanduk, buku saku dan alat peraga untuk membantu dalam ibu mempraktikkan cara menyusui secara benar.

Sarana prasarana yang memadai dan hubungan personal yang baik dalam lingkungan kerja dapat meningkatkan produktivitas kerja. Betapapun positifnya perilaku manusia seperti tercermin dalam kesetiaan yang besar, disiplin yang tinggi, dan dedikasi yang tidak diragukan serta tingkat keterampilan yang tinggi tanpa sarana dan prasarana kerja ia tidak akan dapat berbuat banyak apalagi meningkatkan efisiensi, efektivitas, dan produktivitas kerjanya (Rayadi, 2012).

\section{Hubungan Pengawasan dan Praktik Pemberian ASI Eksklusif}

Berdasarkan hasil analisa bivariat dari 11 orang KP-ASI yang merasa pengawasan kurang terdapat 2 orang $(18,2 \%)$ ibu bayi yang telah menerapkan pemberian ASI secara Eksklusif. Kemudian dari 14 orang KP-ASI termasuk dalam kategori pengawasan yang baik terdapat 4 orang $(28,6 \%)$ ibu yang menerapkan pemberian ASI secara Eksklusif. Berdasarkan hasil uji didapatkan $p$ value $<0,05(0,008)$. Hal ini menunjukkan ada hubungan pengawasan kegiatan Kelompok Pendukung ASI (KPASI) dengan praktik pemberian ASI Eksklusif di Puskesmas Sidomulyo 
Pekanbaru. Nilai OR 11,25 ini menunjukkan bahwa pengawasan kepada KP-ASI yang baik memiliki peluang 11,25 kali lebih besar dalam memberikan pendampingan kepada ibu bayi untuk menerapkan pemberian ASI secara eksklusif.

Melalui hasil penelitian dapat dilihat pengawasan yang baik masih adanya yang belum menerapkan ASI Eksklusif dan juga pengawasan yang kurang namun telah menerapkan ASI Eksklusif, hal ini disebabkan karena pengawasan dilakukan kepada anggota KP-ASI . Menurut asumsi peneliti pengawasan tidak selalu dilakukan ketika KP-ASI sedang melakukan pendampingan pada ibu bayi sehingga pengawasan dirasa belum maksimal. Pengawasan yang baik dapat menunjang kelancaran suatu kegiatan. Sama halnya dengan program KP-ASI yang membutuhkan pengawasan oleh petugas setempat seperti pengawasan oleh petugas puskesmas, petugas kelurahan serta tokoh masyarakat yang ada. Karena dengan pengawasan maka setiap kegiatan dapat dipantau sudah sesuai dengan tugas pokok dan fungsi dan dapat meminimalisir kesalahan dalam melaksanakan kegiatan.

Penelitian ini sejalan dengan penelitian Fikawati (2010) tentang "Penyebab Keberhasilan dan Kegagalan Praktik Pemberian ASI Eksklusif" dengan desain studi adalah studi kualitatif dengan 14 informan yaitu ibu bayi yang berusia $>6-24$ bulan yang dibagi berdasarkan keberhasilan pelaksanaan ASI eksklusifnya. Data dikumpulkan melalui Dinas Kesehatan Kota Pekanbaru. 2019.

Profil Gizi. Pekanbaru

Kementerian Kesehatan RI. SDKI, 2015.

Diakses pada tanggal 6 Maret 2020

dari

http://sdki.bkkbn.go.id/?lang=id.

Mayasari, (2014). Faktor-Faktor yang

Berhubungan dengan Kejadian

Kurang Energi Kronis (KEK) pada

Ibu Hamil di Rumah Bersalin wawancara mendalam dan dilakukan triangulasi sumber data mencakup bidan puskesmas dan suami serta triangulasi analisis oleh pakar. Pendidikan, pengetahuan, dan pengalaman ibu adalah faktor predisposisi yang berpengaruh positif terhadap keberhasilan ASI eksklusif, sedangkan IMD adalah faktor pemungkin yang kuat terhadap keberhasilan ASI eksklusif. Dari segi faktor pendorong, dukungan tenaga kesehatan penolong persalinan paling nyata pengaruhnya dalam keberhasilan pelaksanaan ASI eksklusif. Disisi lain, iklan susu formula di media massa ternyata mempengaruhi keberhasilan ASI eksklusif terutama pada ibu yang berpendidikan rendah.

\section{KESIMPULAN}

Berdasarkan hasil uji Chi Square menujukkan ada hubungan antara motivasi KP-ASI dengan Praktik Pemberian ASI Eksklusif Di Puskesmas Sidomulyo Pekanbaru. Berdasarkan hasil uji Chi Square menujukkan ada hubungan antara ketersediaan sarana prasarana KP-ASI dengan Praktik Pemberian ASI Eksklusif Di Puskesmas Sidomulyo Pekanbaru. Berdasarkan hasil uji Chi Square ada hubungan antara pengawasan KP-ASI dengan Praktik Pemberian ASI Eksklusif Di Puskesmas Sidomulyo Pekanbaru.

\section{DAFTAR PUSTAKA}

Kecamatan Payung Sekaki Kota Pekanbaru Tahun 2014. Skripsi STIKes Hangtuah Pekanbaru.

Mutalazimah. (2006). Pengetahuan dan Sikap. Dikutip dari hasil penelitian Maya sari tahun 2014.

Notoatmodjo, (2005). Metode Penelitian Kesehatan. Jakarta : Rineka Cipta. 
(2012). Promosi Kesehatan dan Perilaku Kesehatan. Jakarta : Rineka Cipta

Nurrahman. 2017. Pengetahuan, Sikap, Dan Praktik Pemberian Asi Eksklusif Di Wilayah Kerja Puskesmas Jumpandang Baru Kecamatan Tallo Kota Makassar. Jurnal Universitas Hasanuddin.

Puskesmas Sidomulyo. 2019. Profil Kesehatan Puskesmas 2019. Pekanbaru

Sutaryono, E. Purwaningsih. 2015. Pembentukan Kelompok Pendukung Air Susu Ibu (ASI) Muhammadiyah Klaten. Universitas Muhammadiyah Semarang

WHO. 2014. Maternal Mortality. Diakses pada tanggal 5 Januari 2019 dari, www.who.int/gho/maternal_health/ mortality/maternal_mortality text. $\underline{204}$

Yuniyanti, B. 2017. Efektivitas Kelompok Pendukung Asi (KP-ASI) Eksklusif terhadap Perilaku Pemberian Asi Eksklusif. Jurnal Ilmiah Bidan 2 (1): 41-47. 